\title{
Integrating the use of natural analogues and erosion modelling in landform design for closure
}

\author{
I Kelder Jacobs, Australia \\ CG Waygood Jacobs, Australia \\ T Willis Emergent Ecology, Australia (formerly Mangoola Open Cut)
}

\begin{abstract}
Landform design methodologies as applied in Australia use primarily one of three methods: Linear and empirical designs that consider primarily materials movement, Landform Evolution Models (such as WEPP or SIBERIA) to assess long-term erodibility of specific material within landforms, and hydrological models that use stable alluvial natural analogues in the local environment as a template for a stable unconsolidated landform shaped by water (typically Geofluv ${ }^{T M}$ or similar).
\end{abstract}

This paper is a case study on the use of elements of all three of these methods on Mangoola Open Cut, a large open cut coal mine in New South Wales, Australia, with a primary focus on the outcomes of an erosion modelling assessment of a Geofluv ${ }^{T M}$ designed landform adapted to meet the site specific requirements.

Construction of the landform commenced in 2012, and the performance to date has been encouraging, based on the short-term, prior to the establishment of vegetation.

Short-term SIBERIA modelling was undertaken to inform the management of erosion risks in the short and long term, and in turn, facilitate ongoing flexibility for the construction of the landform. The modelling will also guide some aspects of revegetation. The modelling predicts that the average overall erosion rate in the long term (500 years) will be similar to the erosion rates of natural landforms in the general area.

\section{$1 \quad$ Background}

Mangoola Open Cut is a $180 \mathrm{Mt}$ open cut mine located near Muswellbrook in New South Wales (NSW), Australia operated by Glencore. Construction on the mine started in 2009, with first coal produced in 2011. It is anticipated that the site will operate until 2029.

The mining area impacts on two creek lines, Anvil Creek and Clarks Gulley. Included within the Development Consent for Mangoola Open Cut, as part of the NSW governmental approval prior to mining commencing, is the requirement to re-establish an equivalent length of drainage lines over the rehabilitated landform.

At the start of the Geofluv ${ }^{\mathrm{TM}}$ landform design process in 2012, construction of the mine had already begun. In the shadow of the global financial crisis, it was necessary that the new landform be constructed within the original rehabilitation budget. The original rehabilitation budget was based on the more generic linear designs widely used within the Hunter Valley, NSW, being a relatively flat upper surface with 1:6 (v: h) side slopes, and drop structures to return runoff to the natural catchment.

The initial design was then reviewed by the design and production team, some modifications made to simplify the construction in non-critical risk areas, and construction commenced. The landform construction was then monitored in terms of cost and performance over the next few years, with the overburden teams becoming increasingly comfortable with the construction and outcomes.

SIBERIA landform evolution modelling (LEM) was undertaken in 2015 to validate the long-term performance of the landform and assess possible areas requiring improvement. The modelling also served 
to delineate some of the higher risk areas for the Geofluv ${ }^{\mathrm{TM}}$ landform in steeper areas still to be constructed.

\section{Approaches to landform design}

Landform design methodologies in the Hunter Valley, NSW, generally use one of three methodologies:

- Empirical designs using typically linear slopes at angles and lengths considered stable in the long term.

- Materials driven methods, using LEM with software such as WEPP and SIBERIA. These models use the erodibility characteristics of the materials present in the landform (determined through geotechnical and flume testing) to assess long-term landform evolution. The models require a landform as a starting point (2D or 3D for WEPP and SIBERIA respectively). WEPP is used to assess a stable 2D slope (frequently a linear slope length with appropriate bench or contour drain spacing). When used as a design tool, SIBERIA uses an iterative modelling process until a 'stable' landform is obtained.

- Methods incorporating the characteristics of stable natural analogues such as Geofluv ${ }^{\mathrm{TM}}$. These methods are being used more readily as the stable natural landforms in the local area usually reflect the characteristics required for a rehabilitated landform. Importantly, for rehabilitated open cut mines, the appropriate analogue is one without elements of rock control, such as an alluvial landform or weathered profile.

Although aspects of all three of these methods were used at Mangoola Open Cut, the primary focus of this paper is the initial Geofluv ${ }^{\mathrm{TM}}$ design (Bugosh 2003), and subsequent erodibility assessment using SIBERIA.

\subsection{Analogue based design}

The Geofluv ${ }^{\mathrm{TM}}$ method requires the documentation and analysis of stable alluvial landforms in the local environment (a natural analogue). Analogues from the Hunter River alluvial floodplain were used as input to the Mangoola Open Cut design. The method has commercially available software (Natural Regrade ${ }^{\circledR}$ ) to design landforms that will have an integrated 3D channel network with the drainage density and a number of other characteristics empirically determined from the natural analogue. As a result, the designs feature predominantly concave slope profiles with a convex to concave inflection point close to the ridge line. The landform also utilises (where gradients are flatter than four per cent) a channel sized for the two year average recurrence interval (ARI) event and a floodplain that can accommodate the 50 year ARI event.

Key parameters used in the Mangoola Open Cut design included:

- Drainage densities (the extent of drainage lines compared to the catchment area) ranging from 20 to $60 \mathrm{~m} /$ hectare across the site, significantly greater than the original drainage densities of 6 to $20 \mathrm{~m} /$ hectare due to the use of the alluvial analogue.

- Slopes on the drainage lines ranging from typically one per cent at the confluence with the natural drainage line up to seven per cent at the headwaters.

- Slopes on the catchment areas not exceeding 18 degrees, although generally significantly flatter than that.

The implementation of the Geofluv ${ }^{\mathrm{TM}}$ method at Mangoola Open Cut required some adaptation to meet the site specific needs, including:

- The use of flood attenuation within the final landform design upslope of Main Pit to contain water during the operational phase. In addition, this facilitates a stable transition and avoids double handling placed overburden. 
- Smoothing of profiles in non-critical areas to simplify the dozing requirements and minimise the construction cost (although the absence of drop structures in the final design has also generated cost savings).

- Incorporation of flexibility in the landform design by identifying non-critical areas, allowing the production team to manage localised variations that arise during mining caused by operational constraints.

The outcomes of the design process are shown in Figures 1 and 2, indicating the original landform design for North Pit and Main Pit compared to the current design.

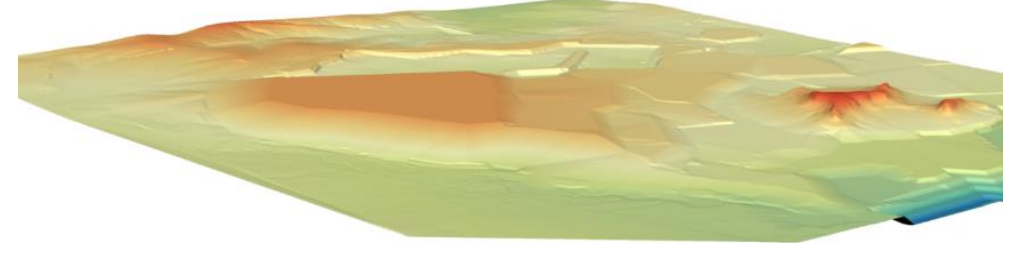

Figure 1 Original landform design (viewed from the southwest)

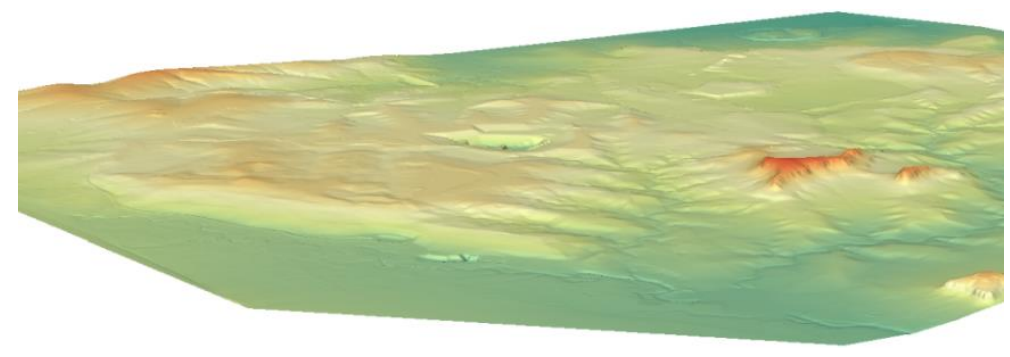

Figure 2 New landform design (viewed from the southwest)

The anticipated final overall landform after rehabilitation is shown in Figure 3, viewed from approximately the same angle as Figures 1 and 2.

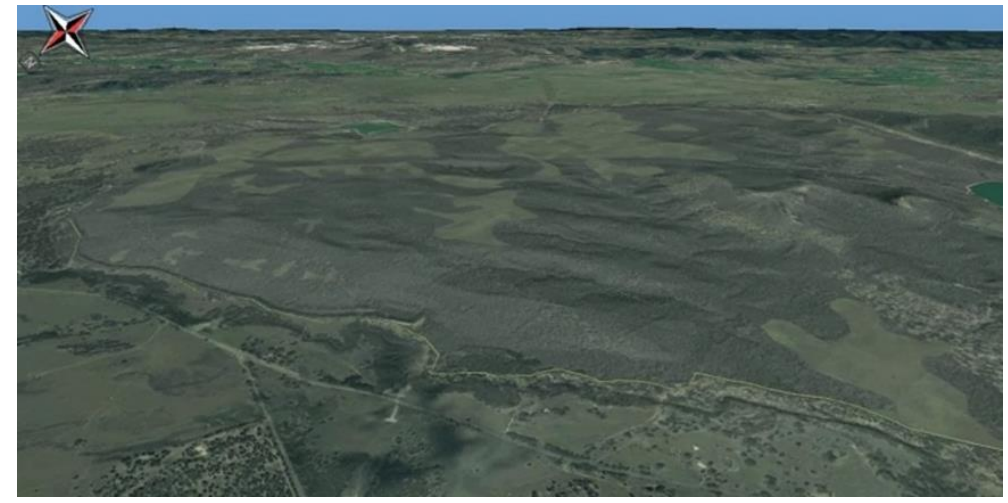

Figure 3 Rehabilitated landform design (viewed from the southwest)

\subsection{Landform evolution modelling}

LEM has progressed significantly over the last 30 years, with the development of models such as SIBERIA and CAESAR able to simulate the landscape in 3D using a digital elevation model. These LEM models are based on representing the physical processes of rainfall and runoff, and associated erosion and deposition. Two models that have been used extensively in the Australian environment are the Water Erosion Prediction Project (WEPP) model (Flanagan \& Nearing 1995), and the SIBERIA landform evolution model (Willgoose et al. 1989).

The SIBERIA model has been used for the erosion assessment of post-mining landforms (Hancock et al. 2008; Willgoose \& Riley 1998) as well as natural catchments (Hancock et al. 2010). SIBERIA has been 
extensively tested and validated at the Ranger Uranium Mine in the Northern Territory, with simulated erosion rates compared to field measured data and similar geomorphic catchments. Based on its successful track record, the SIBERIA model was utilised to assess the final landform at Mangoola Open Cut. Using existing material testing and WEPP analysis (Landloch 2011), the SIBERIA model was calibrated to the site. In addition, input data was evaluated by modelling expert Professor Greg Hancock, based at Newcastle University, NSW, Australia.

It is important to note that erosion models are specifically a landform design tool, that is, they require a starting landform to initiate the modelling process. The models can be used for design, but this requires iterating a landform through an erosion process to determine a stable final profile. By contrast, Natural Regrade $^{\circledR}$ is a design tool which allows the designer greater control in terms of determining a likely stable landform that meets all of the operational requirements.

\section{$3 \quad$ Erosion modelling approach and outcomes}

\subsection{Methodology}

Based on an initial WEPP analysis (Landloch 2011), the preferred rehabilitation strategy utilises a mix of topsoil with weathered conglomerate due to a slightly dispersive nature of the topsoil material. Initial input parameters for SIBERIA were established based on available particle size distribution data, taking into account previously established parameter sets for the region. Initial simulations compared the predicted erosion rates from SIBERIA to those from the WEPP analysis over the same linear slope, and found the rates to be similar, with only small adjustments required to calibrate the model.

To account for different vegetative scenarios, the Universal Soil Loss Equation (USLE) C factor can be input into SIBERIA. The two primary ecological groups planned for the Mangoola Open Cut landform are:

- Grass cover established on flat sections of landform.

- Forested cover system established on slopes and some flat areas.

The USLE C-factors used are summarised in Table 1.

Table 1 USLE C factors

\begin{tabular}{lll}
\hline Description & C factor & Source \\
\hline Grass cover & 0.116 & $\begin{array}{l}\text { Landloch (2011), assuming 30\% canopy cover and } 50 \% \text { contact cover on } \\
\text { the surface. }\end{array}$ \\
Forest cover & 0.04 & $\begin{array}{l}\text { Darwin Harbour Advisory Committee (2010) based on trees with no } \\
\text { understory, average drop fall height of } 4 \mathrm{~m}, \text { with } 50 \% \text { canopy cover and } \\
60 \% \text { ground cover. This parameter was used in the SIBERIA modelling. }\end{array}$ \\
\hline
\end{tabular}

The key input parameters for SIBERIA are given in Table 2. While parameters were derived for all material types, only the conglomerate/topsoil mix was used for rehabilitation and SIBERIA simulations.

Table 2 SIBERIA parameters

\begin{tabular}{llllll}
\hline Description & $\boldsymbol{\beta 1}^{*}$ & $\mathbf{m}^{\mathbf{1}}$ & $\boldsymbol{\beta}^{\mathbf{3}}$ & $\mathbf{m}^{\mathbf{3}}$ & $\mathbf{C}$ factor \\
\hline $\begin{array}{l}\text { Weathered conglomerate and } \\
\text { topsoil mix }\end{array}$ & 0.005 & 1.65 & 1.0 & 1.0 & 0.00 \\
\hline Grass with 30\% basal cover & 0.00058 & 1.65 & 1.0 & 1.0 & 0.116 \\
\hline Forested slopes & 0.0002 & 1.65 & 1.0 & 1.0 & 0.04 \\
\hline
\end{tabular}

*B1 parameter is adjusted to account for c-factor 


\section{$3.2 \quad$ Outcomes}

SIBERIA was used to assess the likely impacts of two scenarios, namely:

- An initial construction phase (two and five year periods) without vegetation (although experience on site suggests vegetation is achieving a reasonable cover within 12 to 18 months).

- Final rehabilitated landform (200 and 500 year period) assuming full grass and forest cover as per the current ecological plan.

Typical outputs from the modelling are shown in Figures 4 and 5 indicating the typical outputs from the SIBERIA model for the short-term construction period, and an overall summary of erosion rates for the entire site. The predicted erosion rates are summarised in Table 3.

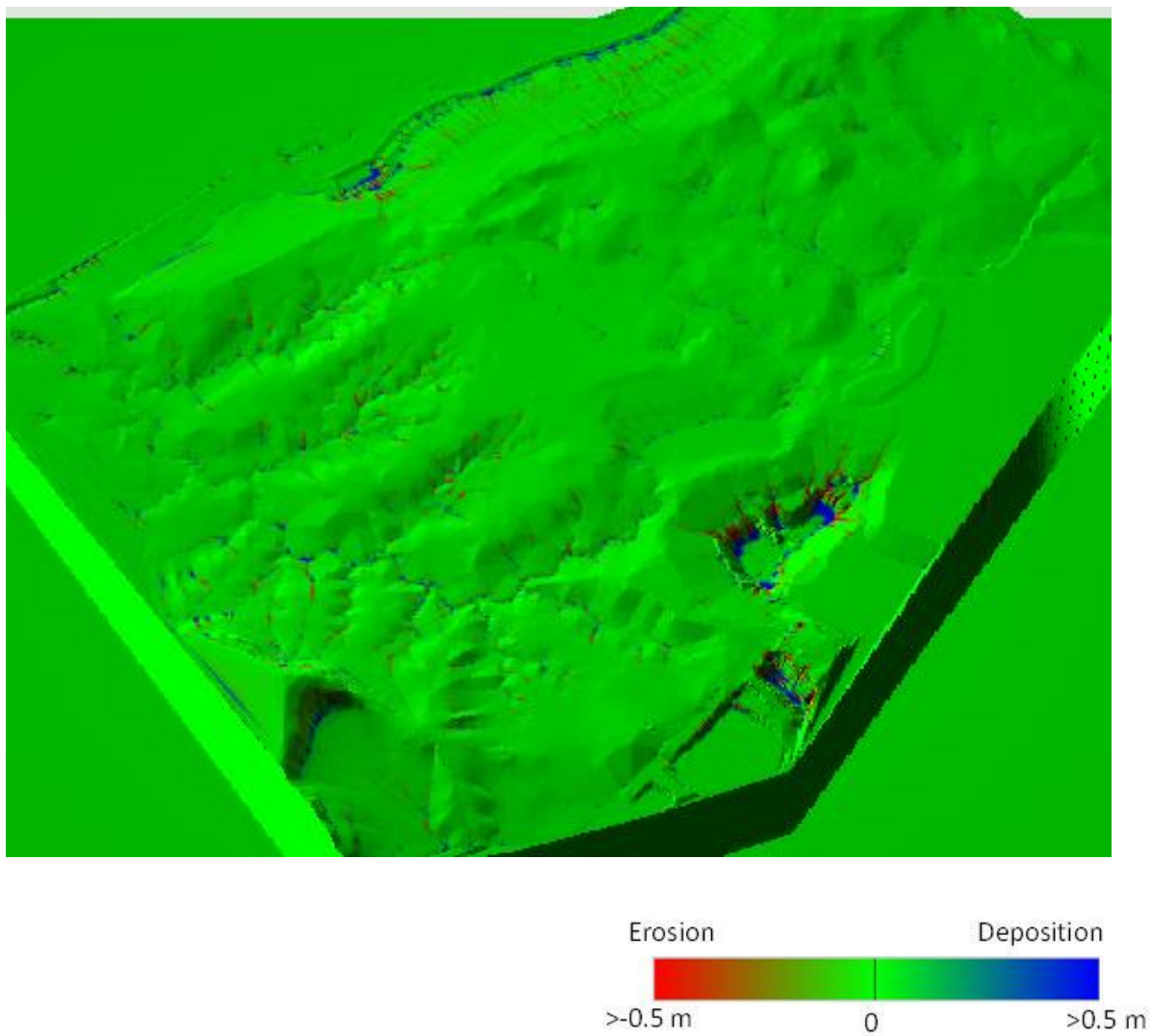

Figure 4 Short-term construction outputs (2 years, no vegetation), northern areas

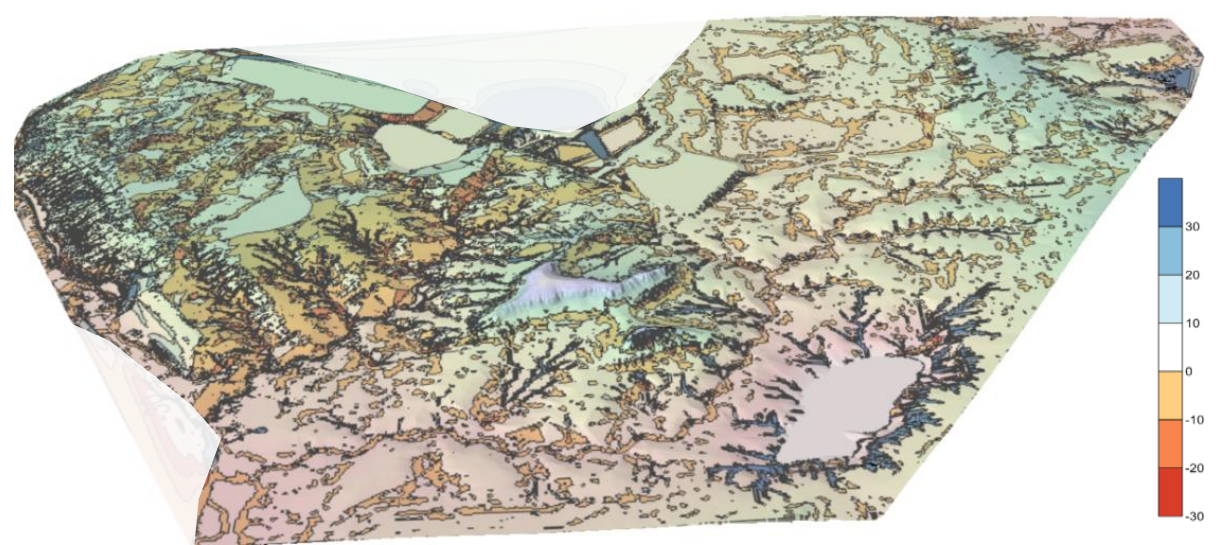

Figure 5 Long-term erosion modelling, summarised erosion rates (t/ha/year) 
Table 3 Erosion rates

\begin{tabular}{lccc}
\hline Analysis & $\begin{array}{c}\text { Erosion rates on steeper } \\
\text { areas (t/ha/year) }\end{array}$ & $\begin{array}{c}\text { Erosion rates on flatter } \\
\text { areas (t/ha/year) }\end{array}$ & $\begin{array}{c}\text { Average erosion rates } \\
\text { (t/ha/year) }\end{array}$ \\
\hline $\begin{array}{l}\text { Construction modelled } \\
\text { over 2 years }\end{array}$ & $25-50$ & $1-6$ & 15 to 25 \\
$\begin{array}{l}\text { Final revegetated } \\
\text { landform after } 500 \text { years }\end{array}$ & $1-4$ & 0.1 & 0.5 to 1 \\
\hline
\end{tabular}

For both the short-term and long-term scenarios, the areas of risk are confined to limited areas on the landform, notably on the outer 1:6 slopes, around the final void, and some slopes on the transition from North Pit to Main Pit.

In the short term, some areas of potential rilling were identified, but the depth and extent of rilling over the Geofluv $^{\mathrm{TM}}$ landform was generally limited, of the order of 0.3 to $0.6 \mathrm{~m}$ in depth. The areas of higher erosion risk in the short term total approximately five per cent of the Geofluv landform ${ }^{\text {TM }}$.

The actual performance of the landform prior to revegetation largely correlates with that modelled by SIBERIA in terms of rill extent and depth, although measured rills are generally less frequent and smaller than predicted. During the first 18 months of construction, within a Geofluv ${ }^{\mathrm{TM}}$ designed area of approximately 50 ha extent, four erosion rills were noted, typically of the order of $0.1 \mathrm{~m}$ in depth, with one $0.3 \mathrm{~m}$ in depth. A typical view of the landform is shown in Figure 6.

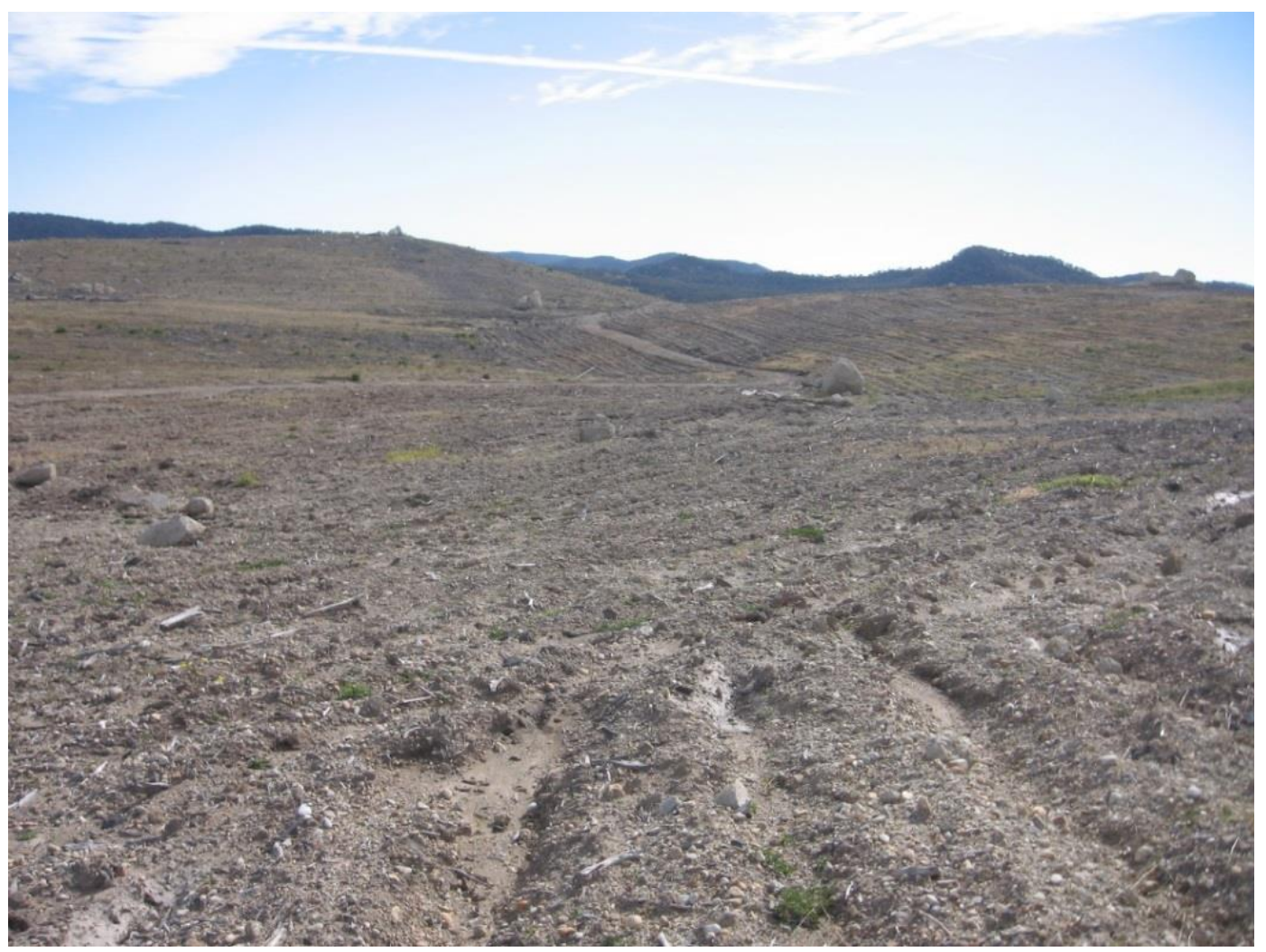

Figure 6 General view of the landform after 18 months

These rills were found to be attributable to deep ripping that deviated from the contour, forming larger catchment areas than the original design. In one case, the rills were related to vehicle tracks running straight up the slope. With the issue of ripping on the contour addressed and additional vehicle controls instituted, rilling of the slopes has become negligible. The operational team involved in the daily construction activities have commented positively on the robustness of the landform to date. 
The overall erosion rates for the long-term erosion modelling were found to be very low, similar to those on natural landforms in the general area. This is considered an endorsement of the landform design, subject to ongoing assessment and calibration through monitoring of the landform. Natural landforms in the Hunter Valley are expected to erode at around 0.4-11.8 t/ha/year as computed using the Caesium-37 method (Elliott \& Dight 1986). The design falls comfortably into the expected erosion rate of natural landforms.

\section{$4 \quad$ Adaptation of ecology to suit the final design}

The Geofluv ${ }^{\mathrm{TM}}$ landform as designed contains features very similar to the natural surrounding landscape such as alluvial flats, low hills, ridgelines and valleys. This provides a platform to reproduce naturally occurring vegetation communities from the surrounding area, many of which are threatened ecological communities listed under State and Commonwealth legislation. This variability in the landform allows the onsite vegetation community specialist to ensure that the different vegetation communities are seeded into the appropriate location within the rehabilitated landform. The advantage of the Upper Hunter Valley is that the vegetation types in this area are typically defined based on topographic position, aspect, slope, and soil type.

At Mangoola Open Cut, topsoil is recovered from mining activities and used in rehabilitation as a growth medium to assist with the establishment of selected vegetation communities. While this is beneficial for the final rehabilitation, operational constraints such as the preferred routes to limit haul distances and occasional stockpiling means that stripped topsoil is not always replaced into the ideal location in terms of topographic position, aspect and slope.

The selection of vegetation communities therefore needs to be flexible to accommodate the range of soil types that are placed on each topographic position, aspect and slope. Broad vegetation community mapping has been undertaken throughout the 1,300 hectare Geofluv ${ }^{\mathrm{TM}}$ landform as part of the Mining Operation Plan. Woodland types are targeted on slopes and creek lines and grassland types are targeted on flatter slopes.

In addition to the final soil type, the specific mixes of a vegetation community are determined by the availability of seed resources. Abundance of early colonising species for each vegetation type has been determined, such as Eucalyptus, Acacia, Dodonaea, Allocasuarina, Hardenbergia, Calotis and several native grass species. In addition to these base species, a range of species more common to both the targeted vegetation community and soil type has been determined. Abundance of each species also varies based on topographic position, aspect, slope, soil type and connectivity across the landscape.

Woodland areas are targeted for both open and dense understory and groundcover based on vegetation establishment in the surrounding landscape. In addition, this mix will provide structural diversity. The variation in climatic factors (specifically rainfall and temperature) also determines density of vegetation communities due to the impact they have on success rates of germination. Infill planting and vegetation have been undertaken in the rehabilitation area to date to assist in achieving the desired densities across the landscape.

\section{Conclusion}

The Mangoola Open Cut landform is, to our knowledge, the first Geofluv ${ }^{\mathrm{TM}}$ based landform constructed in Australia. The design and construction methodology was adapted to meet some of the site specific challenges such as material already placed, and to ensure the rehabilitation cost remained within an existing budget.

The SIBERIA modelling has provided an increased level of confidence in the ability of the design and construction process to deliver a long-term sustainable landform. There are significant environmental benefits compared to the original design. The Geofluv ${ }^{\mathrm{TM}}$ design ensures compliance with the requirements to re-establish creek lines over the mining area. Moreover, combining the natural analogue and materials 
based LEM provides a more complete design process, addressing potential concerns about specific materials within an integrated design process.

While there are still challenges ahead, such as monitoring of settlement to ensure that the drainage lines will transition smoothly back to the natural landform, each year of practical experience with the design, construction and revegetation of the landform is giving increasing confidence that the methodology offers a viable alternative to linear rehabilitation designs.

\section{Acknowledgement}

The authors thank Glencore for permission to publish this paper and for its willingness to consider the use of a Geofluv ${ }^{\mathrm{TM}}$ approach together with SIBERIA modelling for this site; and Umwelt Australia and Jacobs for their roles in the design process.

\section{References}

Bugosh, N 2003, Stream channel design reclamation - The fluvial geomorphic approach to hydrological reclamation, Annual Meeting of the American Society of Mining and Reclamation, Billings, Montana.

Darwin Harbour Advisory Committee 2010, Sediment, nutrients, organic matter and metal inputs to Darwin Harbour from its catchment, and the ecological impacts on the Harbour, Ecosystem Research Group.

Elliot, GL \& Dight, DCG 1986, An evaluation of the surface stability of rehabilitated overburden in the upper Hunter Valley, NSW, report to NSW Coal Association, Sydney.

Flanagan, DC \& Nearing, MA 1995, USDA - Water erosion prediction project, Hillslope profile and watershed model documentation, NSERL Report No. 10, USDA-ARS National Soil Erosion Research Laboratory, West Lafayette, Indiana.

Hancock, G, Loughran, R, Evans, K \& Balog, R 2008, 'Estimation of soil erosion using field and modelling approaches in an undisturbed Arnhem Land catchment, Northern Territory, Australia', Geographical Research, 46(3), pp. 333-349.

Hancock, GR, Lowry, JBC, Coulthard, TJ, Evans, KG \& Moliere, DR 2010, 'A catchment scale evaluation of the SIBERIA and CAESAR landscape evolution models', Earth Surface Processes and Landforms, vol. 35, issue 8, pp. 863-875.

Landloch 2011, RE: Development of recommendations for the Mangoola waste landform, Letter report to Mr Ben Clibborn Environmental \& Community Manager.

Willgoose, G \& Riley, S 1998, 'The long-term stability of engineered landforms of the Ranger Uranium Mine, Northern Territory, Australia: application of a catchment evolution model', Earth Surface Processes and Landforms, vol. 23, pp. 237-259.

Willgoose, GR, Bras, RL \& Rodriguez-Iturbe, I 1989, 'Modelling of the erosional impacts of land use change: A new approach using a physically based catchment evolution model', in Hydrology and Water Resources Symposium 1989, The Institute of Engineers Australia, Melbourne, pp. 325-329. 